\title{
Development and application of a SCAR marker to monitor and quantify populations of the postharvest biocontrol agent Pantoea agglomerans CPA-2
}

\author{
Carla Nunes ${ }^{\mathrm{a}, *}$, Mohammed Bajji ${ }^{\mathrm{b}}$, Valérie Stepien ${ }^{\mathrm{b}}$, Teresa Manso ${ }^{\mathrm{a}}$, Rosario Torres ${ }^{\mathrm{c}}$, \\ Josep Usall ${ }^{\mathrm{c}}$, M. Haïssam Jijakli ${ }^{\mathrm{b}}$ \\ ${ }^{a}$ Centro de Desenvolvimento de Ciências e Técnicas de Produção Vegetal (CDCTPV), \\ University of Algarve, Campus de Gambelas, 8005-117 Faro, Portugal \\ ${ }^{\mathrm{b}}$ Plant Pathology Unit, Gembloux Agricultural University, \\ Passage des Déportés 2, B-5030 Gembloux, Belgium \\ c Postharvest Unit, IRTA, Centre UdL-IRTA, Av. Rovira Roure 191, 25198 Lleida, Catalonia, Spain
}

Received 18 May 2007; accepted 31 July 2007

\begin{abstract}
Pantoea agglomerans CPA-2 is an effective biocontrol agent of postharvest diseases of citrus and pome fruit. A monitoring technique was developed for its identification and to quantify its populations. The methodology used consisted of (i) searching for a semi-selective medium, (ii) identification of molecular markers and (iii) monitoring population dynamics in a commercial trial. As a semi-selective medium, Malonate Broth Agar supplemented with tetracycline hydroxychloride and incubation at high temperature (max. of $40^{\circ} \mathrm{C}$ ) facilitated the selective recovery of $P$. agglomerans CPA-2 colonies. The RAPD technique was applied to a collection of 13 strains of P. agglomerans, including CPA-2. Among the 12 primers tested, OPL-11 amplified a fragment (about 720 bp) specific to strain CPA-2. On the basis of this fragment, two SCAR markers were amplified using a primer pair derived from OPL-11 elongation. A first SCAR marker of $720 \mathrm{bp}$ was specifically amplified for the strain CPA-2 and a second one of $270 \mathrm{bp}$ was obtained for all P. agglomerans strains tested, including CPA-2. Commercial trials demonstrated a significant reduction of decay with the treatment of formulated cells of $P$. agglomerans CPA-2. Population dynamics of CPA-2 in commercial trials were determined on fruit surfaces and in the environment using both the classical plating technique and PCR with SCAR primers. In general, no significant differences were observed between results obtained from the two methods. On fruit surfaces, 1 day after CPA-2 applied its population by classical methods was $4.37 \times 10^{6} \mathrm{cfu}_{\text {wound }}^{-1}$ and at the end of the experiment the population increased to $5.8 \times 10^{5} \mathrm{cfu}^{\mathrm{found}} \mathrm{w}^{-1}$. The percentages of colonies identified as P. agglomerans CPA-2 at these sampling times using SCAR primers were 90 and $95 \%$, respectively. Population dynamics in the environment to evaluate the environmental fate of $P$. agglomerans CPA-2 showed that it has a limited persistence and limited capacity for dispersion.
\end{abstract}

(C) 2007 Published by Elsevier B.V.

Keywords: Biological control; Citrus; Formulate cells; Penicillium digitatum; Penicillium italicum; Postharvest

\section{Introduction}

Biological control using microbial antagonists is an acceptable alternative to synthetic fungicides or as part of an integrated management system to reduce the residues of fungicides on postharvest fruit. A number of microbial antagonists has been patented and evaluated for commercial use as postharvest treat-

\footnotetext{
* Corresponding author. Tel.: +351 289800900; fax: +351 280818419.

E-mail address: canunes@ualg.pt (C. Nunes).
}

ments (Fravel, 2005). To use a biological control agent as a commercial product, it is essential to optimize its formulation (Costa et al., 2000). This is necessary to provide the product in a suitable form in order to optimize efficacy, stability, safety and easy application (Rhodes, 1993).

Recent studies with Pantoea agglomerans CPA-2, isolated from an apple surface (Nunes et al., 2001) showed it controls green and blue moulds on citrus fruit (Teixidó et al., 2001; Torres et al., 2007) and major postharvest diseases on pears and apples (Nunes et al., 2001, 2002b) and a formulated product was consequently developed. Costa et al. (2002b) demonstrated 
that freeze-dried cells of $P$. agglomerans CPA-2 are able to maintain $100 \%$ viability for extended periods without a loss in efficacy.

Apart from practical formulation, identification of strain CPA-2 at the species and strain levels using monitoring tools is needed in for commercial use. Such a tool would be very useful to study the ecological fitness of the strain after its application on fruit, which is crucial for the interpretation and prediction of its biocontrol efficacy in relation to several parameters (formulation, modality of application, storage environment conditions, etc.). Such a tool would also facilitate the registration of CPA-2 and contribute to the establishment of a quality control procedure for the biofungicide.

Several methods have been developed to monitor biocontrol agent populations. Dilution plate methods have been successfully used (Teixidó et al., 1999; Johnson et al., 2000; Nunes et al., 2002a) and have contributed to a better understanding of population dynamics of microorganisms. Nevertheless, these methods have a significant shortcoming because they do not distinguish between introduced and indigenous strains ( $\mathrm{Li}$ et al., 1996). This has led to the development of more specific and more rapid monitoring tools based on DNA amplification (Olive and Bean, 1999). Several of these molecular tools have been developed to specifically detect and monitor a variety of biocontrol agents (De Clercq et al., 2003; Pujol et al., 2004, 2006; Massart et al., 2005; Cordier et al., 2007). In spite of their specificity, these tools are not able to assess a biocontrol population. For this reason, these molecular methods have been combined with dilution plating (De Clercq et al., 2003; Pujol et al., 2006).

When DNA sequences are not available in databases for the design of PCR primers, the search for anonymous target DNA sequences has generally proven to be successful. Random markers as products of the PCR-based random amplified polymorphic DNA (RAPD, Williams et al., 1990) have been widely used because of the simplicity of the method and its ability to discriminate closely related microorganisms without prior knowledge of the target sequences. However, reproducibility can be a problem for the applicability of the RAPD method, especially for weakly amplified bands. Therefore, the RAPD markers are converted into sequence-characterized amplified regions (SCAR) markers (Paran and Michelmore, 1993) which are reproducible, can be organism-specific, and may represent a single locus in the genome, advantages that RAPD markers lack.

The main objectives of the present study were: (i) to develop a SCAR marker for P. agglomerans strain CPA-2 using the RAPD method and (ii) to monitor its population dynamics and environmental fate in a commercial trial using a semi-selective medium and the SCAR marker.

\section{Materials and methods}

\subsection{Fruit}

'Valencia late' oranges (Citrus sinensis) from commercial orchards of the Algarve (southern Portugal), were hand- harvested in May. Fruit were at commercial maturity and were used 1 day after harvest.

\subsection{Antagonist}

P. agglomerans strain CPA-2 was originally isolated from an apple surface and maintained in the Spanish Collection of Type Culture (CECT, University of Valencia, Valencia, Spain). Stock cultures were stored at $5{ }^{\circ} \mathrm{C}$ and sub-cultured on nutrient yeast dextrose agar (NYDA: nutrient broth, $8 \mathrm{~g} \mathrm{~L}^{-1}$; yeast extract, $5 \mathrm{gL}^{-1}$; dextrose, $10 \mathrm{~g} \mathrm{~L}^{-1}$; agar, $20 \mathrm{~g} \mathrm{~L}^{-1}$ ). For the development of molecular markers, a collection of 12 P. agglomerans strains was obtained from Ghent University (Belgium) (Table 1). As for CPA-2, these strains were stored at $5^{\circ} \mathrm{C}$ on NYDA medium.

For the commercial trial, a bacterial suspension was prepared in a bench top fermenter containing $5 \mathrm{~L}$ of sucrose-yeast medium (yeast extract, $5 \mathrm{~g} \mathrm{~L}^{-1}$; sucrose, $10 \mathrm{~g} \mathrm{~L}^{-1}$ ), for $18-22 \mathrm{~h}$ at $30^{\circ} \mathrm{C}$ and $150 \mathrm{~mL} \mathrm{~min}^{-1}$ oxygen rate and $300 \mathrm{rpm}$, as described by Costa et al. (2001), reaching a final population of $5-6 \times 10^{9} \mathrm{cfu} \mathrm{mL}^{-1}$. Cells were harvested at the beginning of the stationary phase by centrifugation at $6981 \times g$ for $10 \mathrm{~min}$ at $15^{\circ} \mathrm{C}$. Cell paste was resuspended in $0.05 \mathrm{M}$ phosphate buffer. $P$. agglomerans cells were freeze-dried as described by Costa et al. (2002b). The formulated preparation consisted of freeze-dried cells with a protective $10 \%$ sucrose solution, and was stored in glass vials at $4{ }^{\circ} \mathrm{C}$ for 3 months. The rehydration medium was non-fat skim milk at $1 \%$.

\subsection{Semi-selective medium}

P. agglomerans strain CPA-2 was sub-cultured twice on NYDA medium. Each sub-culture was incubated at $25^{\circ} \mathrm{C}$ for $24 \mathrm{~h}$. The second sub-culture was then transferred onto either NYDA alone or Malonate Broth Agar (yeast extract, $1 \mathrm{~g} \mathrm{~L}^{-1}$; $\left(\mathrm{NH}_{4}\right)_{2} \mathrm{SO}_{4}, 2 \mathrm{~g} \mathrm{~L}^{-1} ; \mathrm{K}_{2} \mathrm{HPO}_{4}, 0.6 \mathrm{~g} \mathrm{~L}^{-1} ; \mathrm{KH}_{2} \mathrm{PO}_{4}, 0.4 \mathrm{~g} \mathrm{~L}^{-1}$; $\mathrm{NaCl}, 2 \mathrm{~g} \mathrm{~L}^{-1}$; sodium malonate, $3 \mathrm{~g} \mathrm{~L}^{-1}$; glucose, $0.25 \mathrm{~g} \mathrm{~L}^{-1}$; bromthymol blue, $0.025 \mathrm{~g} \mathrm{~L}^{-1}$; agar, $15 \mathrm{~g} \mathrm{~L}^{-1}$ ) (U.S. Food and Drug Administration, 2001) supplemented with $0.1 \mathrm{mg} \mathrm{L}^{-1}$

Table 1

Name, host (geographical origin) and source of Pantoea agglomerans strains used in this study

\begin{tabular}{lll}
\hline Strain & Host (geographical origin) & Source \\
\hline CPA-2 & Malus domestica (Spain) & IRTA, Spain \\
LMG 2565 & Cereals (Canada) & \\
LMG 2569 & Malus sylvestris (USA) & \\
LMG 2570 & Sorbus sp. (USA) & \\
LMG 2572 & Triticum sp. (Canada) \\
LMG 2573 & Cactus tumor \\
LMG 2574 & Avena sativa seed (Scotland) \\
LMG 2585 & Vicia faba seed \\
LMG 2590 & Prunus persica leaf surface \\
LMG 2595 & Allium sapa cv. Granex \\
LMG 2660 & (South Africa) \\
LMG 2744 & Disteria floribunda (Japan) & \\
LMG 2941 & Malus sylvestris leaf surface \\
\hline
\end{tabular}


tetracycline hydroxychloride. Growth on the malonate substrate is a widely used criterion to discriminate bacterial species (Leifson, 1933; Ewing et al., 1957; Brenner, 1984). One hundred microliters of the biocontrol agent $\left(2 \times 10^{3} \mathrm{cfu} \mathrm{mL}^{-1}\right)$ was applied per Petri dish. The average colony number was evaluated every $24 \mathrm{~h}$ during 6 days of incubation at $37^{\circ} \mathrm{C}$. Four replicates were done per medium and the experiment was repeated at least once.

\subsection{Identification of molecular markers}

\subsubsection{DNA extraction}

Two DNA extraction methods were used. The first was used for the development of molecular markers. P. agglomerans was cultured overnight at $25^{\circ} \mathrm{C}$ in NYDB (NYDA medium without agar) and DNA was extracted according to the method described by Ausubel et al. (1993). The second method was used during the application of molecular markers (see hereafter). It is a rapid method of DNA extraction based on Lyse-N-Go PCR Reagent (Pierce) and can be applied on a single colony.

\subsubsection{RAPD analysis}

PCR amplifications were done in a total volume of $25 \mu \mathrm{L}$ containing $2.5 \mu \mathrm{L} 10 \times$ Taq buffer (Tris- $\mathrm{HCl}, 100 \mathrm{mM} ; \mathrm{MgCl}_{2}$, $15 \mathrm{mM}$; $\mathrm{KCl}, 500 \mathrm{mM}$ ), $1.5 \mathrm{mM} \mathrm{MgCl}_{2}, 0.5$ units Taq DNA polymerase (Boehringer Mannheim), $0.2 \mathrm{mM}$ dNTP, $5 \mathrm{pmol}$ primer (Operon Technologies) (Table 2) and $50 \mathrm{ng}$ genomic DNA. DNA amplification was carried out in a peltier thermal cycler (PTC 200) with the following program of an initial cycle of $95^{\circ} \mathrm{C}$ for $5 \mathrm{~min}, 36^{\circ} \mathrm{C}$ for $4 \mathrm{~min}, 72^{\circ} \mathrm{C}$ for $2 \mathrm{~min}$ and 45 cycles of $94^{\circ} \mathrm{C}$ for $25 \mathrm{~s}, 36^{\circ} \mathrm{C}$ for $45 \mathrm{~s}$ and $72^{\circ} \mathrm{C}$ for $1.5 \mathrm{~min}$, followed by a final extension step of $72^{\circ} \mathrm{C}$ for $10 \mathrm{~min}$. PCR products were separated by electrophoresis on $1.5 \%$ agarose gels with TBE buffer and stained with ethidium bromide. Standard DNA samples (Gene Ruler 100 bp DNA Ladder Plus, Fermentas GmbH) were used as molecular size markers.

Table 2

List of RAPD and SCAR primers used in this study

\begin{tabular}{lll}
\hline Type & Primer code & Sequence $\left(5^{\prime}-3^{\prime}\right)$ \\
\hline & OPL-04 & GACTGCACAC \\
& OPL-05 & ACGCAGGCAC \\
& OPL-06 & GAGGGAAGAG \\
& OPL-07 & AGGCGGGAAC \\
& OPL-09 & TGCGAGAGTC \\
RAPD & OPL-11 & ACGATGAGCC \\
& OPM-01 & GTTGGTGGCT \\
& OPM-02 & ACAACGCCTC \\
& OPM-03 & GGGGGATGAG \\
& OPM-04 & GGCGGTTGTC \\
& OPM-05 & GGGAACGTGT \\
& OPM-06 & CTGGGCAACT \\
& PAGA1 & ATGAGCCCTGTGATCAGGAAGATCG \\
& PAGB1 & ACGATGAGCCTTCTCAGCAAATGCG \\
SCAR & PAGA2 & AATGCAGAGCCCTCCTTGTTGGAG \\
& PAGB2 & CAGATCGGAAAGGCGCTTAAGCC \\
& PAGA3 & TTTGCCGTTTGTTGGGCAGGTACTGGC \\
& PAGB3 & CTGACCGGCTTCCCTGCGCTTTAAG \\
\hline
\end{tabular}

\subsubsection{Cloning of RAPD fragments for SCARs}

Specific RAPD amplifications were purified from gel slices by QIAEX II (Qiagen). Purified products were ligated in PCR 2.1 Vector (original TA cloning kit, invitrogen) and transformation of competent Escherichia coli IsNV $\alpha \mathrm{F}$ was performed according to the manufacturer's instructions. The cloned inserts were sequenced with the T7 Sequencing ${ }^{\mathrm{TM}}$ kit (pharmacia biotech). SCAR primer sequences of 23-25 bases were designed (Table 2, Fig. 2).

\subsubsection{Final achievement of SCARs}

Twenty-five microliters of PCR mix were prepared using 0.5 units of Taq DNA polymerase in $1 \times$ buffer (Boehringer Mannheim), $10 \mathrm{ng}$ DNA, $0.2 \mathrm{mM}$ dNTP and $0.4 \mu \mathrm{M}$ of each SCAR primer. A denaturation step of $95^{\circ} \mathrm{C}$ for 5 min was followed by 40 cycles of $95^{\circ} \mathrm{C}$ for $30 \mathrm{~s}, 57^{\circ} \mathrm{C}$ for $30 \mathrm{~s}, 72^{\circ} \mathrm{C}$ for $30 \mathrm{~s}$ and by a final extension step of $72{ }^{\circ} \mathrm{C}$ for $5 \mathrm{~min}$. The samples were stored at $4{ }^{\circ} \mathrm{C}$. Reaction products were resolved by electrophoresis on $1.5 \%$ agarose gels stained with ethidium bromide and visualized with UV light.

\subsection{Commercial trial using P. agglomerans CPA-2 formulation}

A commercial trial was conducted in a packinghouse with 'Valencia late' oranges with natural postharvest decay infections to verify the effectiveness of the $P$. agglomerans CPA-2 formulation. Treatments were CPA-2 formulation containing $2 \times 10^{8} \mathrm{cfu} \mathrm{mL}^{-1}$, imazalil (Fecundal ${ }^{\circledR}$, Janssen, USA, $7.5 \mathrm{~g} \mathrm{~L}^{-1}$ of active ingredient) at $1250 \mu \mathrm{g} \mathrm{mL}^{-1}$, or water at ambient temperature $\left(20 \pm 2{ }^{\circ} \mathrm{C}\right)$. Each treatment was applied to a minimum of three replicates of 500 fruit each. Treatments were applied by dipping oranges for $30 \mathrm{~s}$ in each solution in a water tank $(150 \mathrm{~cm} \times 60 \mathrm{~cm} \times 60 \mathrm{~cm})$. Fruit were maintained for $24 \mathrm{~h}$ at $20^{\circ} \mathrm{C}$ and then stored for 6 days at $7{ }^{\circ} \mathrm{C}$ followed by 21 days at ambient temperature $\left(20 \pm 1^{\circ} \mathrm{C}\right)$. After this period, the incidence of decay was evaluated.

\subsection{Monitoring P. agglomerans CPA-2 populations by molecular detection}

This assay was conducted in order to identify P. agglomerans CPA-2 from the indigenous microflora, to monitor its population dynamics on the fruit surface and to evaluate its distribution within the environment of the packinghouse. The population of $P$. agglomerans CPA-2 formulation was monitored in the commercial trial. Fruit were wounded in four locations and the population of the formulation was monitored at days $0,1,7$, 14, 21 and 27. The treatment was repeated six times with five oranges each and four pieces of peel surface of $2.5 \mathrm{~cm}$ (with the wounds) of each orange were removed using a cork borer. Peel surface was placed in $50 \mathrm{~mL}$ of $0.05 \mathrm{M}$ phosphate buffer and shaken on a rotary shaker for $20 \mathrm{~min}$ at $150 \mathrm{rpm}$ and then sonicated for $10 \mathrm{~min}$ in an ultrasound bath. Serial 10 -fold dilutions of washings were made and plated on the semi-selective Malonate Broth Agar medium and incubated for 4 days at $37^{\circ} \mathrm{C}$. 
Population size was expressed as cfu wound ${ }^{-1}$. To distinguish $P$. agglomerans CPA-2 from the other strains, yellow colonies morphologically similar to $P$. agglomerans were randomly selected on plates of days $0,1,7$ and 27 . The number of colonies selected was a maximum of 25 colonies per plate, but always at least $20 \%$ of all colonies per plate were selected for PCR tests using SCAR primers. The percentage of the colonies identified as CPA-2 was calculated and results are shown as log cfu wound ${ }^{-1}$.

The distribution of CPA-2 within the packinghouse environment was evaluated on Malonate Broth Agar medium. Samples were taken from the gloves and working clothes worn during the commercial assay by using a sterile swab stick at day 1 and plated on Petri dishes. Environmental distribution was monitorized by opening Petri dishes for $2 \mathrm{~min}$ in room treatment at days 1 and 7, in cold chamber at day 7 and in fruit storage chamber at day 27. On surfaces, CPA-2 populations were evaluated by printing Rodac plates in the tank of treatment after cleaning and rinsing at day 1 , and from the inside and outside of fruit boxes at days 1, 7 and 27. All plates were incubated at $37{ }^{\circ} \mathrm{C}$ for 4 days and PCR tests were conducted as described previously.

\subsection{Statistical analysis}

The incidence of decayed fruit was analyzed using analysis of variance conducted after square root transformation to improve homogeneity of variances. P. agglomerans population was analyzed by two-way factorial analysis and population size (cfu wound ${ }^{-1}$ ) was $\log$ transformed to improve homogeneity. Statistical significance was judged at the level of $P<0.05$ and least significant difference (LSD) procedure was used to separate means.

\section{Results}

\subsection{Semi-selective medium}

The selectivity of 27 different media based on NYDA medium containing various antibiotics or fungicides (alone or in combination) was tested on the air microflora and none of these media allowed $P$. agglomerans strain CPA-2 growth in comparison with the control medium (NYDA) (data not shown). Difficulties in finding a semi-selective medium adapted to this bacterial strain were mainly due to its sensitivity to antibiotics. These problems have been solved by using a higher growth temperature $\left(\max .40^{\circ} \mathrm{C}\right.$ ) and a more specific carbon supply (Malonate Broth Agar) supplemented with $0.1 \mathrm{mg} \mathrm{L}^{-1}$ tetracycline hydroxychloride. In these conditions, the number of strain CPA-2 colonies after an incubation period of $48 \mathrm{~h}$ at $40^{\circ} \mathrm{C}$ was similar in both control (NYDA, $109.8 \pm 4.3$ cfu plate $^{-1}$; Malonate Broth Agar, $99.0 \pm 6.2 \mathrm{cfu}^{-1 a t e^{-1}}$ ) and semi-selective (Malonate Broth Agar $+0.1 \mathrm{mg} \mathrm{L}^{-1}$ tetracycline hydroxychloride and $101.3 \pm 5.3 \mathrm{cfu}$ plate ${ }^{-1}$ ) media and did not change after 4 days of additional incubation (data not shown). No growth was observed in plates previously exposed to the microflora of the air (data not shown).

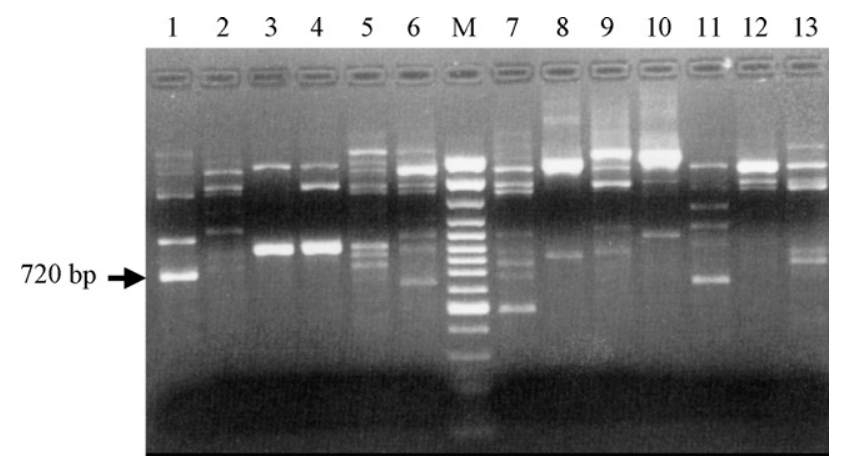

Fig. 1. RAPD patterns obtained using Pantoea agglomerans strains and OPL11 primer. lane 1, CPA-2; lane 2, LMG 2565; lane 3, LMG 2569; lane 4, LMG 2570; lane 5, LMG 2572; lane 6, LMG 2573; lane 7, LMG 2574; lane 8, LMG 2585; lane 9, LMG 2590; lane 10, LMG 2595; lane 11, LMG 2660; lane 12, LMG 2744; lane 13, LMG 2941; Lane M, GeneRuler ${ }^{\mathrm{TM}} 100$ bp DNA Ladder Plus. The arrow indicates the DNA fragment of $720 \mathrm{bp}$ which was specifically amplified for the strain CPA-2.

\subsection{Identification of molecular markers}

In a first step, we performed a rapid analysis on the reference strain (CPA-2) and two others (LMG 2565 and LMG 2569, Table 1) to screen potential DNA markers. Out of the 12 primers (Table 2) used in this first screening, six (OPL-04, OPL05, OPL-11, OPM-02, OPM-03 and OPM-06) provided specific amplification products for CPA-2 (data not shown). The screening of the complete collection of $P$. agglomerans (Table 1) using these six RAPD primers led to the selection of primer OPL-11, which had a specific DNA fragment for strain CPA-2 (Fig. 1). This fragment was cloned and partially sequenced (Fig. 2). Six SCAR primers derived from OPL-11 elongation (three forward: PAGA1, PAGA2 and PAGA3; three reverse: PAGB1, PAGB2 and PAGB3) (Table 2, Fig. 2) were designed and were used to screen the total collection of P. agglomerans (Table 1). Different primer pairs were tested at different annealing temperatures (data not shown). A first SCAR marker of 720 bp was specifically amplified with PAGA1/PAGB1 for strain CPA-2 at both 57 and $59^{\circ} \mathrm{C}$ annealing temperatures (Fig. 3). A second one of $270 \mathrm{bp}$ was amplified for all P. agglomerans strains, including CPA-2,

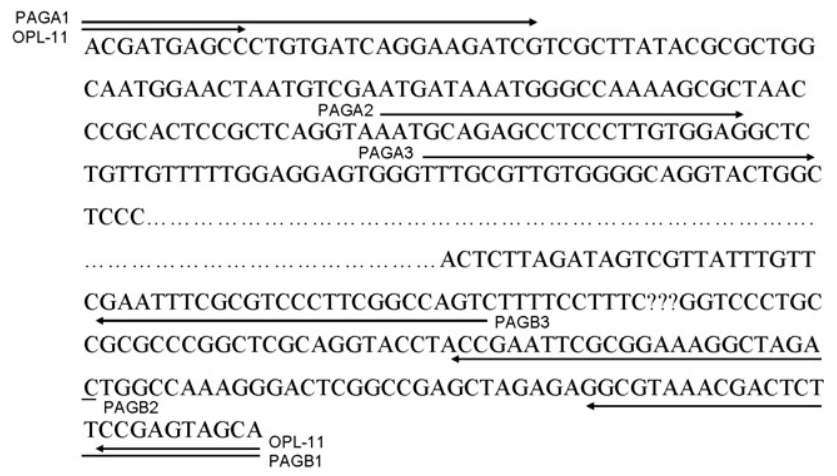

Fig. 2. Partial sequence of the $720 \mathrm{bp}$ DNA fragment which was amplified specifically for $P$. agglomerans strain CPA-2 using OPL-11 primer. Lines (arrows) correspond to sequences of OPL-11 and three pairs of SCAR primers (PAGA1/PAGB1, PAGA2/PAGB2 and PAGA3/PAGB3). 


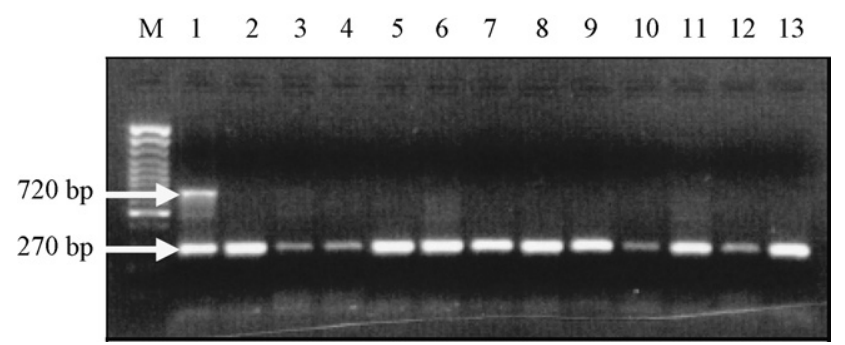

Fig. 3. SCAR markers obtained with PAGA1/PAGB1 primers at $57^{\circ} \mathrm{C}$ annealing temperature. The first one ( $720 \mathrm{bp}$ ) is specific to strain CPA-2 and the second one ( $270 \mathrm{bp}$ ) may be specific to P. agglomerans species. Lane M, GeneRuler ${ }^{\mathrm{TM}}$ 100 bp DNA Ladder Plus; lane 1, CPA-2; lane 2, LMG 2565; lane 3, LMG 2569; lane 4, LMG 2570; lane 5, LMG 2572; lane 6, LMG 2573; lane 7, LMG 2574; lane 8, LMG 2585; lane 9, LMG 2590; lane 10, LMG 2595; lane 11, LMG 2660; lane 12, LMG 2744; lane 13, LMG 2941. Arrows indicate the molecular size of both SCAR markers.

using the same pair of primers and seems thus to be specific to the species (at least based on the strains tested here). When used on other strains belonging to other species (e.g. Pichia anomala strains J121 and K and Candida oleophila strain O), these SCAR primers did not amplify any product (data not shown).

\subsection{Commercial trial using P. agglomerans CPA-2 formulation}

Results of the commercial trial on oranges are shown in Fig. 4. The formulation of $P$. agglomerans CPA-2 strongly inhibited the development of decay. The incidence of decay was reduced to $4.1 \%$ while in the control fruit the decay incidence was $7.5 \%$ (Fig. 4, total); nevertheless, the best result was obtained with the fungicide imazalil (IZ). Concerning pathogens, CPA-2 was most effective against Penicillium digitatum, the incidence being reduced by $56 \%$. Regarding Penicillium italicum and other fungi, no significant reduction was found compared to the control. However, the incidence caused by P. italicum and other fungi was much lower (less than $0.8 \%$ ) in comparison to P. digitatum.

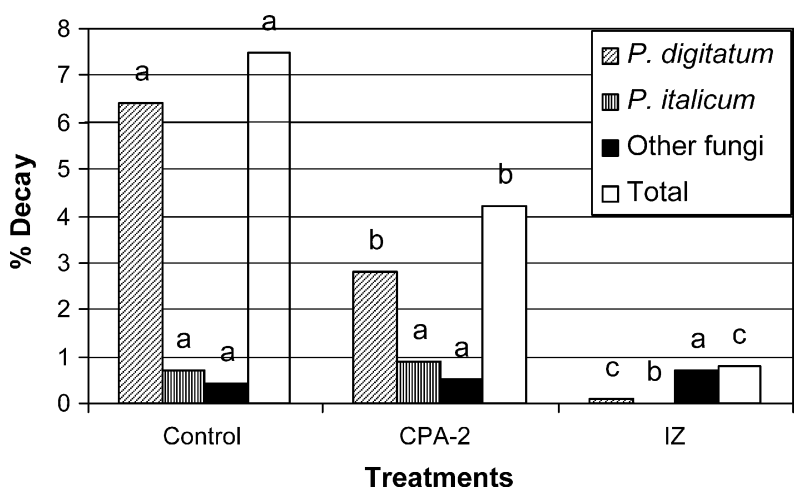

Fig. 4. Commercial assay using formulated cells of P. agglomerans CPA-2. Nonwounded oranges that developed natural infections were treated by dipping for $30 \mathrm{~s}$ in $2 \times 10^{8} \mathrm{cfu} \mathrm{mL} \mathrm{m}^{-1}$, imazalil (IZ) $1250 \mu \mathrm{g} \mathrm{mL}^{-1}$ and water at ambient temperature. Fruit were maintained for $24 \mathrm{~h}$ at $20^{\circ} \mathrm{C}$ and then stored for 6 days at $7^{\circ} \mathrm{C}$ followed by 21 days at ambient temperature. Each treatment was applied to a minimum of three replicates of 500 fruit each. Within pathogens, columns with the same letter are not significantly different according to the LSD test.

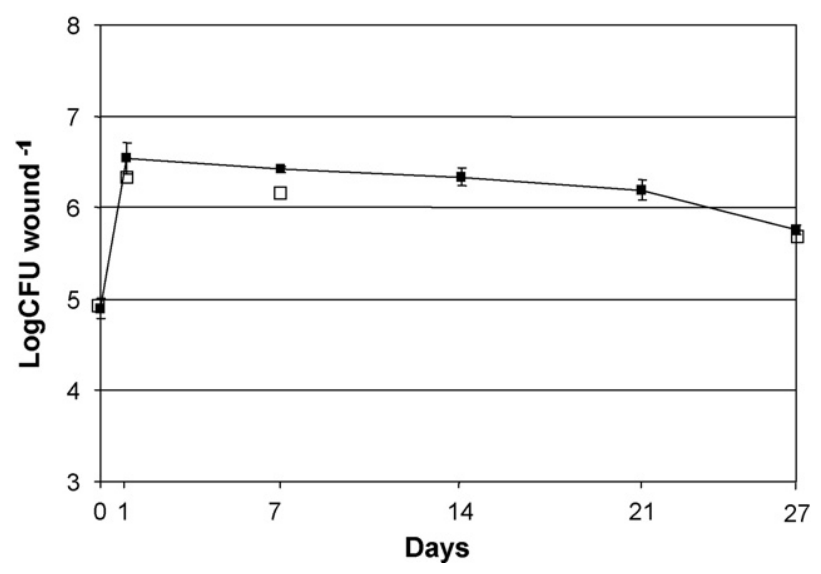

Fig. 5. Population dynamics of formulated cells of P. agglomerans CPA-2 on wounded oranges. Oranges were wounded and treated by dipping for $30 \mathrm{~s}$ in a suspension of CPA-2 at $2 \times 10^{8} \mathrm{cfu} \mathrm{mL}^{-1}$. Fruit were maintained for $24 \mathrm{~h}$ at $20^{\circ} \mathrm{C}$ and then stored for 6 days at $7{ }^{\circ} \mathrm{C}$ followed by 21 days at ambient temperature. Population was monitored on a Malonate Broth Agar medium followed by ( ) classical determination of cfu on agar and ( $\square$ ) identification by PCR with SCAR primers.

\subsection{Monitoring P. agglomerans CPA-2 populations by molecular detection}

Population dynamics of CPA-2 within fruit wounds are shown in Fig. 5. At time 0, the population recovered from fruit was $8.7 \times 10^{4} \mathrm{cfu}_{\text {wound }}{ }^{-1}$. During the first $24 \mathrm{~h}$ at $20^{\circ} \mathrm{C}$, the CPA-2 population increased approximately 50 -fold and reached a level of $4.3 \times 10^{6} \mathrm{cfu}$ wound $^{-1}$. Then, the rate of growth slightly decreased and reached $2.2 \times 10^{6} \mathrm{cfu}$ wound $^{-1}$ at day 14. After this time, growth decreased and reached $5.8 \times 10^{5}$ cfu wound $^{-1}$ at the end of the experiment. No statistical differences, except for day 7 , were observed between the population recovered and the percentage is identified as strain CPA-2. At time 0 and at the end of the experiment, $90 \%$ of the recovered cfu wound ${ }^{-1}$ were identified as P. agglomerans CPA-2.

The evaluation of environmental distribution of $P$. agglomerans CPA-2 from different ambient conditions and surfaces showed that it had brief persistence and little capacity for dispersion within the packinghouse. The yellow colonies morphologically similar to $P$. agglomerans sampled from the different surfaces confirmed the presence of CPA- 2 only on gloves worn during the commercial assay and at days 1 and 7 inside the boxes where fruit were stored. From the aerial environment, CPA-2 strain was not identified at any sampling time (data not shown).

\section{Discussion}

P. agglomerans strain CPA-2, originally isolated from the surface of an apple, has been shown to be reliably effective, alone or in combination with other (bio)products, in controlling green and blue moulds on citrus fruit as well as the major postharvest diseases on apples and pears under various environmental conditions (e.g. Teixidó et al., 2001; Nunes et al., 2001, 2002a,b,c; Torres et al., 2007). Other work related to the modes of action 
of this strain and to its production and viability has also been published (Costa et al., 2000, 2001, 2002a; Poppe et al., 2003). This indicates that $P$. agglomerans strain CPA-2 could serve as the basis of a new biocontrol product. Its ability to control multiple diseases in different hosts is an added value that makes it an interesting commercial product. Ongoing studies to develop this strain as a biopesticide have created the need to develop a monitoring method for tracking it and knowing its environmental fate after its application.

Monitoring methods can be grouped into cultivation- or nucleic acid-based methods (Van Elsas et al., 1998). The first consist in counting colony forming units on a Petri dish on a selective or semi-selective medium (Johnson et al., 2000; Usall et al., 2001; De Clercq et al., 2003). In the present work, we encountered difficulties in developing a semi-selective medium for strain CPA-2 due to its great sensitivity to antibiotics. We have solved this problem by using a higher growth temperature (max. $40^{\circ} \mathrm{C}$ ) and a more specific carbon supply (Malonate Broth Agar) supplemented with $0.1 \mathrm{mg} \mathrm{L}^{-1}$ tetracycline hydroxychloride. Such microbiological methods have the advantage to detect viable microorganisms only, but they would have a lack of specificity if there were non-targeted microorganisms with the same morphological characteristics able to grow on the medium used. Nucleic acid-based methods have higher specificity but they do not discriminate between living and dead cells so they may overestimate viable population levels, especially under stress conditions (Pujol et al., 2006). This unambiguous identification of a specific strain of a microorganism based on antibiotic resistance and morphological characteristics remains thus difficult and limits the routine application of this approach. To overcome this lack of specificity, counting colony forming units on a solid semi-selective medium can be combined with PCR screening of randomly chosen colonies. SCAR markers have been commonly used to develop monitoring methods for biological agents (e.g. Schena et al., 2002; De Clercq et al., 2003; Cordier et al., 2007) because they are natural sequences present in the genome that allow a simple specific detection by PCR. The most important and significant advantage of these markers is that they do not require any prior knowledge of the strain genome. In this work, RAPD has been used to analyze the molecular variability within 13 different strains of $P$. agglomerans, including CPA-2. By using the decamer OPL-11, a DNA fragment of $720 \mathrm{bp}$ has been obtained for strain CPA-2 only. Even though RAPD profiles could be used as a monitoring method, it is preferable to convert them into SCAR markers which (i) simplify the detection with a single band instead of a profile, (ii) are more specific as they target a known sequence and (iii) are less sensitive due to stringency of the PCR conditions. After cloning and partial sequencing of the $720 \mathrm{bp}$ fragment specific to strain CPA-2, a set of SCAR primers derived from OPL-11 elongation was used to screen the total collection of P. agglomerans. Two SCAR markers were amplified using the PAGA1/PAGB1 pair of primers; a first one specific to strain CPA-2 and a second one always present in all P. agglomerans strains tested and may be specific to the species. The sequence of the SCAR primers we have designed may thus be repeated along the genome.
$P$. agglomerans formulated cells grew well on the surface of oranges during cold storage. Maintaining the fruit for $24 \mathrm{~h}$ at $20^{\circ} \mathrm{C}$ before cold storage increased the population size of $P$. agglomerans strain CPA-2 more than 10-fold, which suggests that this time is necessary for the biocontrol agent to colonize the fruit surface. In fact, in a previous work (Teixidó et al., 2001) when fruit were stored at cold temperature after treatments with fresh cells of $P$. agglomerans, the population size decreased during the first 3 days, and then increased (10-fold) after 7 days of cold storage. Since the mode of action of $P$. agglomerans CPA-2 seems to be competition for nutrients (Poppe et al., 2003), its efficacy may be related to its concentration. Maintaining the fruit during $24 \mathrm{~h}$ at $20^{\circ} \mathrm{C}$ could lead to an increase of the population size of our biocontrol agent to levels that enhanced its biocontrol activity.

The use of biocontrol agents in commercial conditions creates a need to distinguish the particular strain applied from the indigenous microflora, so molecular identification for strain CPA-2 of P. agglomerans was developed. The analysis of yellow colonies morphologically similar to $P$. agglomerans was applied with success to confirm the identification of $90 \%$ of the most isolates recovered from wounded fruit and plated on the semi-selective Malonate Broth Agar medium. The combination of the mixed monitoring methods, classical dilution plate and PCR screening using SCAR primers of randomly chosen colonies shows excellent promise to effectively follow the population dynamics of CPA-2 during storage and to evaluate its distribution in the environment. Sampling $20 \%$ of the yellow colonies from fruit surface plate dilutions indicated approximately $90 \%$ confirmation of the colonies as strain CPA-2, adding confidence and specificity to the results of population dynamics study, showing that these combined methods could be used under practical conditions. This mixture of methods has been applied successfully in quantification of $P$. anomala strain $\mathrm{K}$ on apple fruit surfaces (De Clercq et al., 2003).

Regarding the environmental distribution and persistence, the technique shows that $P$. agglomerans CPA-2 has a low impact since it did not grow and disperse in the environment, which is very important for application in packinghouses and especially in the field, because this suggests it would have little effect on indigenous microflora and may facilitate registration.

The use of a semi-selective medium combined with the SCAR marker we have developed in the present study may have a great practical importance. However, more research is still needed to reduce the time and temperature of incubation, to shorten and simplify the DNA extraction for routine application, and to test our SCAR marker on a large number of different $P$. agglomerans strains from various hosts and geographical origins for a specific monitoring and quantification of CPA-2 population.

\section{Acknowledgments}

The authors are grateful to the European Community (QLK51999-01065), to the Portugal Government (Fundação para a Ciência e a Tecnologia) (SFRH/BPD/26797/2006) and to the Spanish Government (Ministerio de Educación y Ciencia) 
(Ramon y Cajal contract) for its financial support and the packinghouse Tavifruta for their technical assistance in commercial trial.

\section{References}

Ausubel, F.M., Brent, R., Kingston, R.E., Moore, D.M., Seidman, J.G., Smith, J.A., Struhl, K. (Eds.), 1993. Current Protocols in Molecular Biology. Greene Publishing Associates and Wiley-Interscience, New York.

Brenner, D.J., 1984. Family I: enterobacteriaceae. In: Krieg, N.R., Holt, J.G. (Eds.), Bergey's Manual of Systematic Bacteriology, vol. 1. The Williams \& Wilkins Co., Baltimore, pp. 408-516.

Cordier, C., Edel-Hermann, V., Martin-Laurent, F., Blal, B., Steinberg, C., Alabouvette, C., 2007. SCAR-based real time PCR to identify a biocontrol strain (T1) of Trichoderma atroviride and study its population dynamics in soils. J. Microbiol. Methods 68, 60-68.

Costa, E., Usall, J., Teixidó, N., Garcia, N., Viñas, I., 2000. Effect of protective agents, rehydration media and initial cell concentration on viability of Pantoea agglomerans strain CPA-2 subjected to freeze-drying. J. Appl. Microbiol. 89, 793-800.

Costa, E., Teixidó, N., Usall, J., Atarés, E., Viñas, I., 2001. Production of the biocontrol agent Pantoea agglomerans strain CPA-2 using commercial products and by-products. Appl. Microbiol. Biotechnol. 56, 367-371.

Costa, E., Teixidó, N., Usall, J., Fons, E., Gimeno, V., Delgado, J., Viñas, I., 2002a. Survival of Pantoea agglomerans strain CPA-2 in a spray-drying process. J. Food Prot. 65, 185-191.

Costa, E., Usall, J., Teixidó, N., Torres, R., Viñas, I., 2002b. Effect of package and storage conditions on viability and efficacy of the freeze-dried biocontrol agent Pantoea agglomerans strain CPA-2. J. Appl. Microbiol. 92, 873-878.

De Clercq, D., Cognet, S., Pujol, M., Lepoivre, P., Jijakli, M.H., 2003. Development of a SCAR marker and a semi-selective medium for specific quantification of Pichia anomala strain K on apple fruit surfaces. Postharvest Biol. Technol. 29, 237-247.

Ewing, W.H., Davis, B.R., Reavis, R.W., 1957. Phenylalanine and malonate media and their use in enteric bacteriology. Public Health Lab. 15, 153-167.

Fravel, D.R., 2005. Commercialization and implementation of biocontrol. Annu. Rev. Phytopathol. 43, 337-359.

Johnson, K.B., Stockwell, V.O., Sawyer, T.L., Sugar, D., 2000. Assessment of environmental factors influencing growth and spread of Pantoea agglomerans on and among blossoms of pear and apple. Phytopathology 90, 1285-1294.

Leifson, E., 1933. The fermentation of sodium malonate as a mean of differentiating Aerobacter and Escherichia. J. Bacteriol. 26, 329-330.

Li, S., Cullen, D., Hjort, M., Spear, R., Andrews, J.H., 1996. Development of an oligonucleotide probe for Aureobasidium pullulans based on the smallsubunit rRNA gene. Appl. Environ. Microbiol. 62, 1514-1518.

Massart, S., De Clercq, D., Salmon, M., Dickburt, C., Jijakli, M.H., 2005. Development of real-time PCR using minor groove binding probe to monitor the biological control agent Candida oleophila (strain O). J. Microbiol. Methods $60,73-82$.

Nunes, C., Usall, J., Teixidó, N., Viñas, I., 2001. Biological control of postharvest pear diseases using a bacterium Pantoea agglomerans CPA-2. Int. J. Food Microbiol. 70, 53-61.
Nunes, C., Usall, J., Teixidó, N., Abadias, M., Vinas, I., 2002a. Improved control of postharvest decay of pears by the combination of Candida sake (CPA-1) and ammonium molybdate. Phytopathology 92, 281-287.

Nunes, C., Usall, J., Teixidó, N., Fons, E., Viñas, I., 2002b. Postharvest biological control by Pantoea agglomerans (CPA-2) on golden delicious apples. J. Appl. Microbiol. 92, 247-255.

Nunes, C., Usall, J., Teixidó, N., Torres, R., Viñas, I., 2002c. Control of Penicillium expansum and Botrytis cinerea on apples and pears with the combination of Candida sake and Pantoea agglomerans. J. Food Prot. 65, 178-184.

Olive, M., Bean, P., 1999. Principles and applications of methods for DNA-based typing of microbial organisms. J. Clin. Microbiol. 37, 1661-1669.

Paran, I., Michelmore, R.W., 1993. Development of reliable PCR-based markers linked to downy mildew resistance genes in lettuce. Theor. Appl. Genet. 85, 985-993.

Poppe, L., Vanhoutte, S., Hofte, M., 2003. Modes of action of Pantoea agglomerans CPA-2, an antagonist of postharvest pathogens on fruits. Eur. J. Plant Pathol. 109, 963-973.

Pujol, M., De Clercq, D., Cognet, S., Lepoivre, P., Jijakli, M.H., 2004. Monitoring system for the biocontrol agent Pichia anomala strain K using quantitative competitive PCR-ELOSA. Plant Pathol. 53, 103-109.

Pujol, M., Badosa, E., Manceau, C., Montesinos, E., 2006. Assessment of the environmental fate of the biological control agent of fire blight, Pseudomonas fluorescens EPS62e, on apple by culture and real-time PCR methods. Appl. Environ. Microbiol. 72, 2421-2427.

Rhodes, D.S., 1993. Formulation of biological control agents. In: Jones, D.G. (Ed.), Exploitation of Microorganisms. Chapman \& Hall, London, pp. 411-445.

Schena, L., Sialer, M.F., Gallitelli, D., 2002. Molecular detection of strain L47 of Aureobasidium pullulans, a biocontrol agent of postharvest diseases. Plant Dis. 86, 54-60.

Teixidó, N., Usall, J., Viñas, I., 1999. Efficacy of preharvest and postharvest Candida sake biocontrol treatments to prevent blue mould on apples during cold storage. Int. J. Food Microbiol. 50, 203-210.

Teixidó, N., Usall, J., Palou, L., Asensio, A., Nunes, C., Viñas, I., 2001. Improving control of green and blue molds of oranges by combining Pantoea agglomerans (CPA-2) and sodium bicarbonate. Eur. J. Plant Pathol. 107, 685-694

Torres, R., Nunes, C., García, J.M., Abadias, M., Viñas, I., Manso, T., Olmo, M., Usall, U., 2007. Application of Pantoea agglomerans CPA-2 in combination with heated sodium bicarbonate solutions to control the major postharvest diseases affecting citrus fruit at several mediterranean locations. Eur. J. Plant Pathol. 118, 73-83.

U.S. Food and Drug Administration, 2001. Bacteriological Analytical Manual online. U.S. Food and Drug Administration, Center for Food and Safety and Applied Nutrition, College Park, MD, http://www.cfsan.fda.gov/ $\sim$ ebam/bam-toc.html

Usall, J., Teixidó, N., Torres, R., Ochoa de Eribe, X., Viñas, I., 2001. Pilot tests of Candida sake (CPA-1) applications to control postharvest blue mold on apple fruit. Postharvest Biol. Technol. 21, 147-156.

Van Elsas, J.D., Duarte, G.F., Rosado, A.S., Smalla, K., 1998. Microbiological and molecular biological methods for monitoring microbial inoculants and their effects in the soil environment. J. Microbiol. Methods 32, 133-154.

Williams, J.G., Kubelik, A.R., Livak, K.J., Rafalski, J.A., Tingey, S.V., 1990. DNA polymorphisms amplified by arbitrary primers are useful as genetic markers. Nucl. Acid Res. 18, 6531-6535. 